\title{
Patient with X-linked phenotype of SCID, markedly skewed maternal X-inactivation, but normal common gamma chain (CD132) gene ORF sequence
}

\author{
Anna-Claire Coleman ${ }^{1 *}$, Andrew C Issekutz ${ }^{1}$, Christie Riddell ${ }^{2}$, Elie Haddad ${ }^{3}$, Thomas B Issekutz ${ }^{1}$ \\ From Canadian Society of Allergy and Clinical Immunology Annual Scientific Meeting 2012 \\ Calgary, Canada. 11-14 October 2012
}

\section{Background}

A 7.5-month old male presented with increasing respiratory distress progressing to severe hypoxia, an erythematous scaling rash and a paucity of lymphoid tissue. Chest $\mathrm{x}$-ray revealed bilateral pneumonia with diffuse alveolar opacities. He had an increased neutrophil count, normal hemoglobin and platelet count, and an absolute lymphocyte count of $4.3 \times 10^{9} / \mathrm{L}$ decreasing to $1.8 \times 10^{9} / \mathrm{L}$. IgG was $1.72 \mathrm{~g} / \mathrm{l}$, IgA $0.59 \mathrm{~g} / \mathrm{l}$ and IgM $1.08 \mathrm{~g} / \mathrm{l}$, but no antibody to tetanus, diphtheria or pneumococcus despite immunization. Nasopharyngeal aspirate demonstrated rhinovirus by PCR, and tracheal aspirate was positive for Pneumocytis jiroveci by immunofluoresence. Lymphocyte markers showed: $62 \% \mathrm{CD} 19^{+}, 24 \% \mathrm{CD} 4^{+}, 1 \% \mathrm{CD}^{+}$cells and $0.5 \%$ NK cells. $\mathrm{CD}^{+}{ }^{+}$cells were $90 \% \mathrm{CD}_{4} \mathrm{RO}^{+}, 8 \% \mathrm{CD}_{4} 5 \mathrm{RA}^{+}$and $5 \%$ were $\mathrm{CD} 25^{+}$. His cells had no proliferative response to anti-CD3 or IL-2 stimulation, a weak response to PHA, and no response to antigen or MLR. BMT was performed from a HLA-identical sister and the patient is well 7 months post BMT.

\section{Conclusion}

The decreased and non-functional T cells, absence of NK cells and normal number of B cells, and lack of proliferation to IL-2 is typical of X-linked common gamma chain or JAK3 deficient SCID. DNA sequencing showed no sequence variants in the ORF of the common gamma chain, but the patient's mother has an abnormal lymphocyte subset profile and maternal $\mathrm{T}$ cells are markedly skewed to use one $\mathrm{X}$-chromosome (non-random), while B

\footnotetext{
* Correspondence: colanna@gmail.com

'Department of Pediatrics, Dalhousie University, Halifax NS, Canada

Full list of author information is available at the end of the article
}

cells demonstrate random $\mathrm{X}$-inactivation. Investigations are underway to assess whether this patient has an unusual form of X-linked SCID.

\begin{abstract}
Author details
${ }^{1}$ Department of Pediatrics, Dalhousie University, Halifax NS, Canada. ${ }^{2}$ Department of Molecular Diagnostics, IWK Health Centre, Halifax, NS, Canada. ${ }^{3}$ Department of Pediatric Immunology and Rheumatology, CHU Sainte-Justine, Montreal, QC, Canada.
\end{abstract}

Published: 2 November 2012

doi:10.1186/1710-1492-8-S1-A24

Cite this article as: Coleman et al:: Patient with X-linked phenotype of SCID, markedly skewed maternal X-inactivation, but normal common gamma chain (CD132) gene ORF sequence. Allergy, Asthma \& Clinical Immunology 2012 8(Suppl 1):A24.
Submit your next manuscript to BioMed Central and take full advantage of:

- Convenient online submission

- Thorough peer review

- No space constraints or color figure charges

- Immediate publication on acceptance

- Inclusion in PubMed, CAS, Scopus and Google Scholar

- Research which is freely available for redistribution Submit your manuscript at
www.biomedcentral.com/submit C) BioMed Central

\section{Ciomed Central}

